\title{
High-Temperature X-Ray Study of the System $\mathrm{Fe}_{3} \mathrm{O}_{4}-\mathrm{Mn}_{3} \mathrm{O}_{4}$
}

\author{
By H. F. McMurdie, Barbara M. Sullivan, and Floyd A. Mauer
}

\begin{abstract}
A series of compositions in the system $\mathrm{Fe}_{3} \mathrm{O}_{4}-\mathrm{Mn}_{3} \mathrm{O}_{4}$ was prepared and examined at high temperatures by $\mathrm{X}$-ray diffraction methods. Although $\mathrm{Fe}_{3} \mathrm{O}_{4}$ and $\mathrm{Mn}_{3} \mathrm{O}_{4}$ form a continuous series of substitutional solid solutions stable at room temperatures, those compositions containing less than 60 percent of $\mathrm{Mn}_{3} \mathrm{O}_{4}$ are cubic, of the spinel type, and the rest are tetragonal. Those compositions that are tegragonal at room temperature pass through a two-phase region when heated and acquire the cubic spinel-type structure at high temperatures. The temperature range of the two-phase (exsetution) region varies with composition. The relation to this system of the minerals vredenburgite and hausmannite is discussed.
\end{abstract}

\section{Introduction}

A few years ago, while the oxides of manganese were being studied in this laboratory [1], ${ }^{1}$ it was found that $\mathrm{Mn}_{3} \mathrm{O}_{4}$, on being heated, inverts from the tetragonal structure to a cubic form of the spinel type at $1,170^{\circ} \mathrm{C}$.

The low temperature form of $\mathrm{Mn}_{3} \mathrm{O}_{4}$ (hausmannite) is tetragonal, with $a=5.75 \mathrm{~A}$ and $c=9.44$ A [2]. A larger unit cell, which is more readily compared in volume and atomic arrangement to that of the spinel-type [3] $\mathrm{Mn}_{3} \mathrm{O}_{4}$ obtained at higher temperatures, may be constructed by considering $a$ equal to the diagonal of the cross section of the unit cell normal to $c$. When the two forms are compared in this way, it is found that the inversion involves only a slight distortion of the structure. As the change from tetragonal to cubic at $1,170^{\circ} \mathrm{C}$. requires little change in structure, it is rapid and reversible as would be expected.

Since $\mathrm{Fe}_{8} \mathrm{O}_{4}$ and $\mathrm{Mn}_{3} \mathrm{O}_{4}$ are known to combine to give cubic spinel-type structures (jacobsite), the inversion of pure $\mathrm{Mn}_{3} \mathrm{O}_{4}$ described above suggests that a study of the system $\mathrm{Fe}_{3} \mathrm{O}_{4}$ $\mathrm{Mn}_{3} \mathrm{O}_{4}$ would be of interest.

\section{Previous Studies}

The main previous work on the system $\mathrm{Fe}_{3} \mathrm{O}_{4}$ $\mathrm{Mn}_{3} \mathrm{O}_{4}$ is that of Mason [4], from whose dissertation the diagram in figure 1 is reproduced.

\footnotetext{
1 Figures in brackets indicate the literature references at the end of this paper.
}

The System $\mathrm{Fe}_{3} \mathrm{O}_{4}-\mathrm{Mn}_{3} \mathrm{O}_{4}$
Mason prepared a series of compounds by coprecipitating mixtures of the hydroxides of iron and manganese and heating the precipitate at approximately $1,200^{\circ} \mathrm{C}$ to obtain the proper state of oxidation. In this way, homogeneous preparations covering the range from 20 to 100 mole percent of $\mathrm{Mn}_{3} \mathrm{O}_{4}$ were obtained.

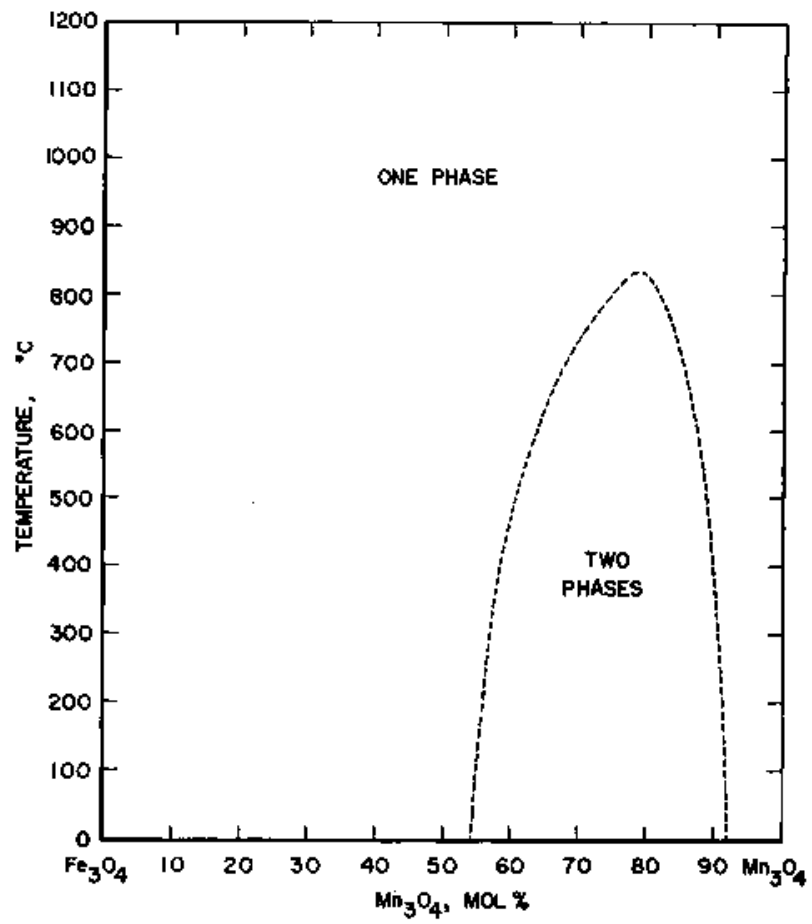

Frgure 1. Diagram of the system $\mathrm{Fe}_{3} \mathrm{O}_{4}-\mathrm{Mn}_{3} \mathrm{O}_{4}$ after Mason [4]. 
These preparations were studied by means of powder photographs. The samples containing less than 60 percent of $\mathrm{Mn}_{3} \mathrm{O}_{4}$ gave cubic patterns, whereas those containing more than 60 percent of $\mathrm{Mn}_{3} \mathrm{O}_{4}$ were tetragonal. The tetragonal form showed a gradual increase in axial ratio with increase in manganese content. The axial ratio varied from unity (at 60 percent of $\mathrm{Mn}_{3} \mathrm{O}_{4}$ ) to 1.16 (for pure $\mathrm{Mn}_{3} \mathrm{O}_{4}$ ). Mason assumed that inasmuch as these compounds were formed near $1,200^{\circ} \mathrm{C}$, they represented the conditions at that temperature and were not in equilibrium at room temperature. This interpretation seemod to be confirmed by the existence in nature of the mineral vredenburgite. This mineral has been found by X-ray diffraction and microscopy $[5,6]$ to be composed of two phases, one cubic and the other tetragonal. The presence of these two phases indicates that the mineral is formed by exsolution. According to Mason, this two-phase mineral represents equilibrium conditions at room temperature, and on the basis of an analysis of the two phases present, he indicated an area of immiscibility in the portion of the system between 54 and 91 percent of $\mathrm{Mn}_{3} \mathrm{O}_{4}$. His approximation of the region in which exsolution would occur is outlined in figure 1. He did not indicate the position of the boundary between the cubic and the tetragonal phases in the one phase region.

In Mason's survey of the minerals comprising the system $\mathrm{Fe}_{3} \mathrm{O}_{4}-\mathrm{Mn}_{3} \mathrm{O}_{4}$, he fixed limits of composition for four minerals: magnetite, jacobsite, vredenburgite, and hausmannite. According to him, "Vrodenburgite signifies those substances whose composition lies within the area of immiscibility, i. e., between 54 and 91 percent $\mathrm{Mn}_{3} \mathrm{O}_{4}$." The name hausmannite was given to substances in this system containing from 91 to 100 percent of $\mathrm{Mn}_{3} \mathrm{O}_{4}$. The remainder of the system, from pure $\mathrm{Fe}_{3} \mathrm{O}_{4}$ to 54 percent of $\mathrm{Mn}_{3} \mathrm{O}_{4}$, was arbitrarily divided at a composition corresponding to 50 percent of $\mathrm{Fe}_{3} \mathrm{O}_{4}$ and 50 percent of $\mathrm{MnFe}_{2} \mathrm{O}_{4}$, that is, at 16.7 percent of $\mathrm{Mn}_{3} \mathrm{O}_{4}$. Substances containing less than 16.7 percent of $\mathrm{Mn}_{3} \mathrm{O}_{4}$ were called magnetite, and those containing from 16.7 to 54 percent of $\mathrm{Mn}_{3} \mathrm{O}_{4}$ were designated jacobsite. The two-phase mineral vredenburgite was believed by Mason to represent equilibrium conditions at room temperature and was therefore called $\beta$-vredenburgite. The name $\alpha$-vredenburgite was reserved for a high-temperature form that Mason expected to find. Later [7], he did find minerals in this range of composition that consisted of a single tetragonal phase.

Von Eckermann [8] suggested that the change from the cubic to the tetragonal structure might take place at a different composition if the temperature were increased. Basing his hypothesis on Mason's paper, and on earlier work by Montoro [9], he suggested that compositions high in $\mathrm{Mn}_{3} \mathrm{O}_{4}$ might remain tetragonal up to the melting point, whereas those richer in iron would change on heating from cubic to tetragonal at approximately $1,000^{\circ} \mathrm{C}$. As Mason pointed out in a later paper $[10]$, such a change to lower symmetry on heating seems unlikely.

When work in this laboratory disclosed that heating pure $\mathrm{Mn}_{3} \mathrm{O}_{4}$ brought about a change from the tetragonal to the cubic structure at $1,170^{\circ} \mathrm{C}$, it became evident that further work was needed to clarify the picture of the high-temperature portion of the system. Because of the rapid inversions that occur in this system, it is not practical to investigate the phase relations by examination of quenched samples. High-temperature X-ray diffraction studies seemed to be the only practical method of attacking the problem, and, since suitable equipment was available [11], work was undertaken to revise the diagram of the system.

\section{Method and Materials}

The high-temperature X-ray diffraction apparatus described by Van Valkenburg and McMurdie [11] was employed to hold the specimens at various temperatures while the diffraction patterns were being made. Unfiltered FeK radiation was used, and the patterns were automatically recorded on a Geiger-counter spectrometer. The equipment used can record only those lines for which the Bragg angle is less than $45^{\circ}$. For this reason, it was not possible to determine the cell dimensions with the accuracy attained by Mason.

A series of mixtures at intervals of 5 percent by weight ${ }^{2}$ from 60 to 100 percent of $\mathrm{Mn}_{3} \mathrm{O}_{4}$ was prepared by a method similar to that of Mason. Manganous and ferrous sulfates were weighted out in the proper proportions and dissolved. The hydroxides were coprecipitated with $\mathrm{NaOH}$

2 Although Mason's compositions are expressed in mole percent and those in this paper in weight percent, the difference in this system is very slight. 
and washed by centrifuging until free from sulfates. The precipitates were then heated at $1,200^{\circ} \mathrm{C}$ for approximately 18 hours to convert them to the desired state of oxidation. Analysis of several of the samples for iron and manganese showed that the composition was as originally planned in each case.

$\mathrm{X}$-ray diffraction patterns of each of the samples were recorded at room tcmperature and at various elevated temperatures. When a pattern was recorded at a high temperature, the sample was usually held at that temperature for about half an hour. Recording the pattern required about 40 minutes, after which the sample was raised to the next temperature without intermediate cooling. In a few cases samples were held at one temperature for periods up to 24 hours. The change in the relative amounts of the two phases during this period was so slight that it seemed reasonable to assume that the samples were at equilibrium when held at one temperature for half an hour.

In order to prevent oxidation of the sample at temperatures between $200^{\circ}$ and $1,000^{\circ} \mathrm{C}$, it was necessary to pass a stream of nitrogen through the furnace. In no case where nitrogen was used did lines of the higher oxide appear.

\section{Results}

Table 1 shows the phases present and the unitcell dimensions ${ }^{3}$ for each of the samples at various temperatures. These data show that, at room temperature, each sample consists of a single phase, the one containing 60 percent of $\mathrm{Mn}_{3} \mathrm{O}_{4}$ being cubic while all others are tetragonal. When the samples containing 65 to 95 percent of $\mathrm{Mn}_{3} \mathrm{O}_{4}$

\footnotetext{
As mentioned previously, a modifled unit cell has been used to describe the tetragonal pbase. The cell chosen facilitates comparison with spinel structures.
}

TABLE 1. Unit-cell dimensions of compositions in the system $\mathrm{Fe}_{3} \mathrm{O}_{4}-\mathrm{Mn}_{1} \mathrm{O}_{4}$ at various temperatures

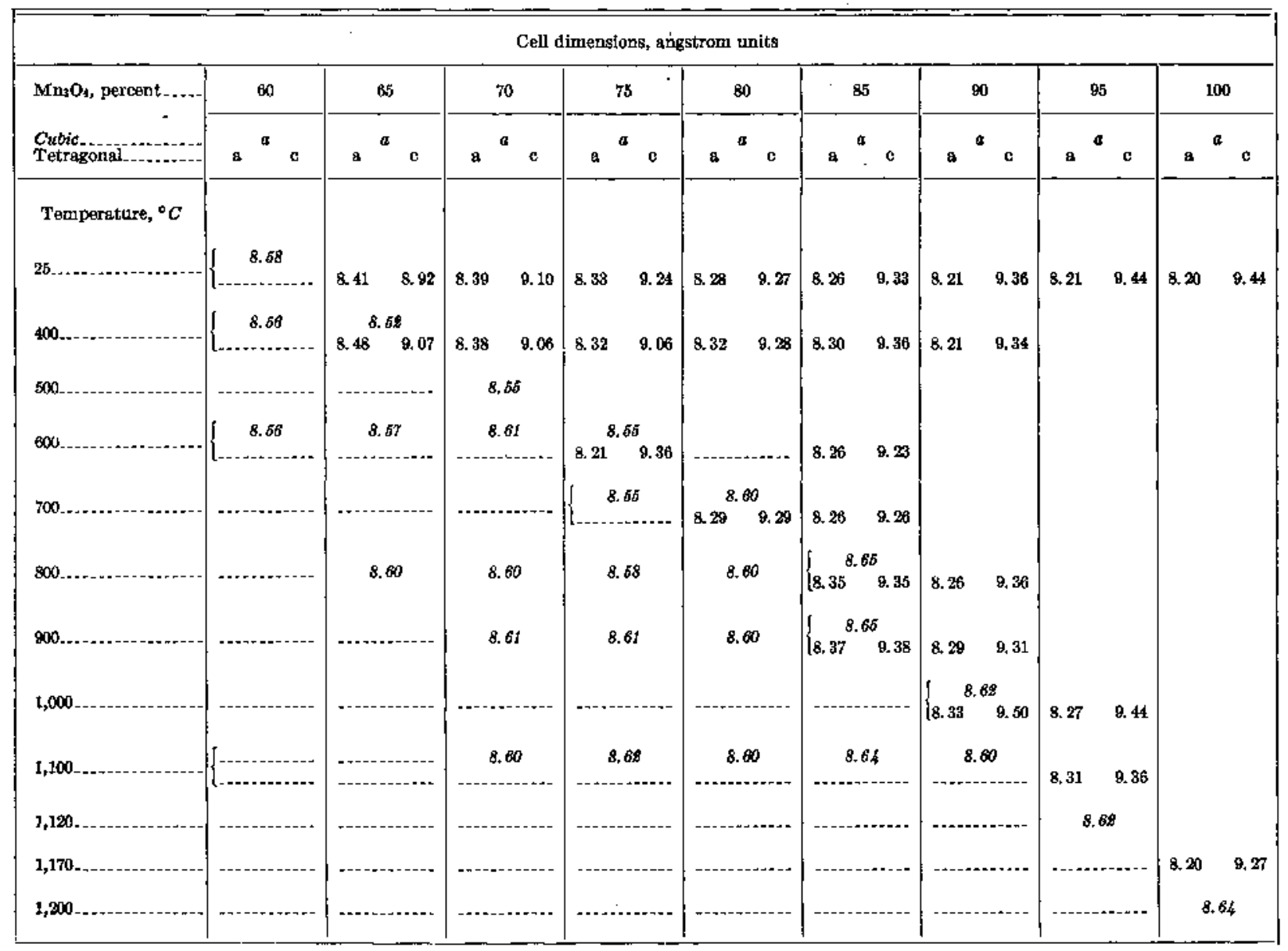


are heated, each passes from the tetragonal phase through a region in which both the tetragonal and cubic phases are in equilibrium. At high temperatures the cubic phase alone is present. The pure $\mathrm{Mn}_{3} \mathrm{O}_{4}$, of course, passes directly from the tetragonal to the cubic form with no twophase region. As any one sample is heated to a temperature near the inversion point, the axial ratio does not approach unity as one might expect. The only change in unit-cell dimensions is a slight over-all increase due to thermal expansion. For this reason, the cubic and tetragonal patterns do not become indistinguishable at the inversion point.

Although the 60-percent $\mathrm{Mn}_{3} \mathrm{O}_{4}$ sample gave a cubic pattern at room temperature, this pattern was characterized by poorly defined peaks and considerable line broadening. The fact that the pattern improved when the temperature of the sample was raised to $600^{\circ} \mathrm{C}$ indicates that the cubic phase is probably not stable at room temperature. The cubic pattern obtained can be attributed to the fact that the samples were held at $1,200^{\circ} \mathrm{C}$ during preparation, at which temperature all would exist in the cubic phase. The 60-percent- $\mathrm{Mn}_{3} \mathrm{O}_{4}$ sample appears to have been quenched when cooled to room temperature, and it was impossible to observe any transition on reheating. Extrapolation from data obtained for samples of higher $\mathrm{Mn}_{3} \mathrm{O}_{4}$ content indicates that, in the case of the 60-percent- $\mathrm{Mn}_{8} \mathrm{O}_{4}$ sample, the cubic and tetragonal phases should be in equilibrium at about $400^{\circ} \mathrm{C}$. The specimen was held at this temperature for a period of 24 hours, but there was no significant change in the pattern obtained at the end of this time. The furnace temperature was then manually lowered in small steps over a period of 2 days. When the temperature of the specimen was lowered to $250^{\circ} \mathrm{C}$ the lines characteristic of the tetragonal phase were discernible. The specimen was eventually cooled to room temperature, but the tetragonal pattern was still not distinct, and the cubic pattern showed some line broadening, indicating that the lattice was under strain. Thus, while it seems reasonable to assume that the cubic form containing 60 percent of $\mathrm{Mn}_{3} \mathrm{O}_{4}$ is not at equilibrium at room temperature, the tendency to supercool makes it impossible to obtain a specimen that is tetragonal. Data on samples containing 50 and 55 percent of $\mathrm{Mn}_{3} \mathrm{O}_{4}$ would be desirable, but because of the slower rate of inversion of compositions in this range, it does not seem likely that one could be reasonably sure that the patterns obtained represented the conditions at the temperature used during the test.

In figure 2 the results obtained from the patterns made at elevated temperatures are plotted. Points have been plotted for each of the samples to show the highest temperature at which the tetragonal phase alone was discernible, the lowest and highest temperature at which both the cubic and tetragonal phases could be detected, and the lowost temperature at which the cubic phase appeared alone. It should be borne in mind that a second phase may not be detected if it constitutes less than 10 percent of the specimen. Figure 2 shows the temperature range over which two phases could be distinguished, but it must be assumed that traces of the second phase too small to detect may be present outside this temperature range. As explained above, no satisfactory data

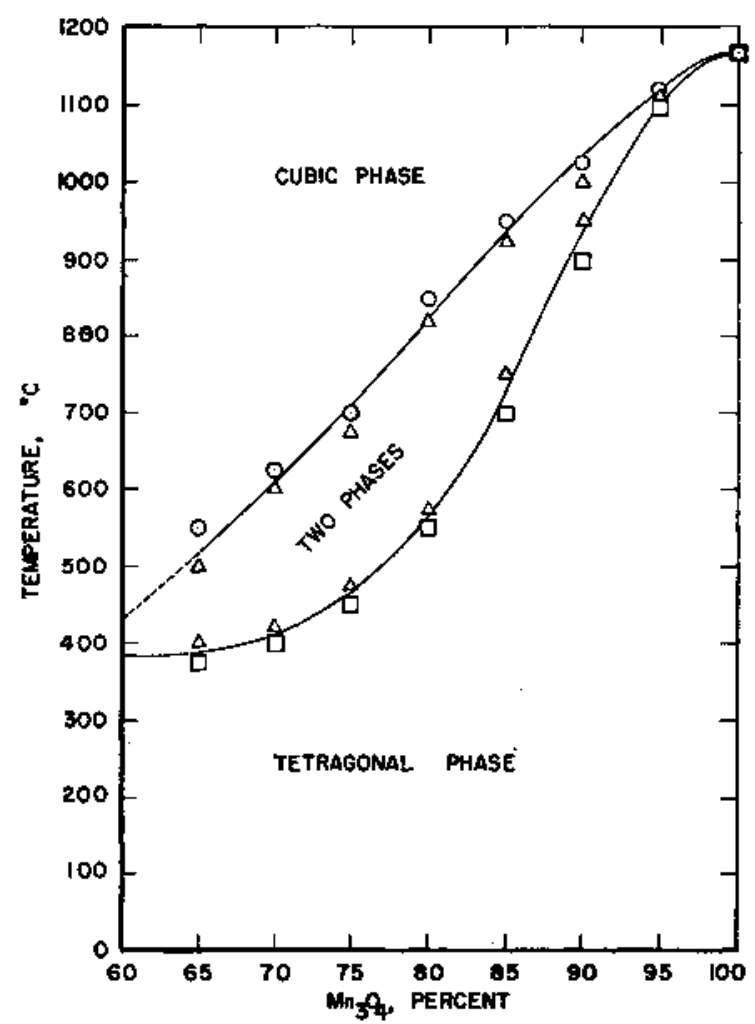

Fiqure 2. Partial diagram of the system $\mathrm{Fe}_{3} \mathrm{O}_{4}-\mathrm{Mn}_{3} \mathrm{O}_{4}$.

$\square$, Highcst temperature at which the tetragonal-phase alone was discernible; $\triangle$, limits of the temperature range over which both the cubic and tetra5onal phases could be detected; $O$, Jowest temperature at which the cubio phase appeared alone. 
were obtained for the 60 -percent sample. The dotted portion of the curve indicates the probable limits of the two-phase region at this end of the curve. As shown in the figure, the pure $\mathrm{Mn}_{3} \mathrm{O}_{4}$ inverts at $1,170^{\circ} \mathrm{C}$ and has no two-phase region.

The cell dimensions at room temperature are shown in figure 3 , and the dimensions for both phases occurring at $600^{\circ} \mathrm{C}$ appear in figure 4 .

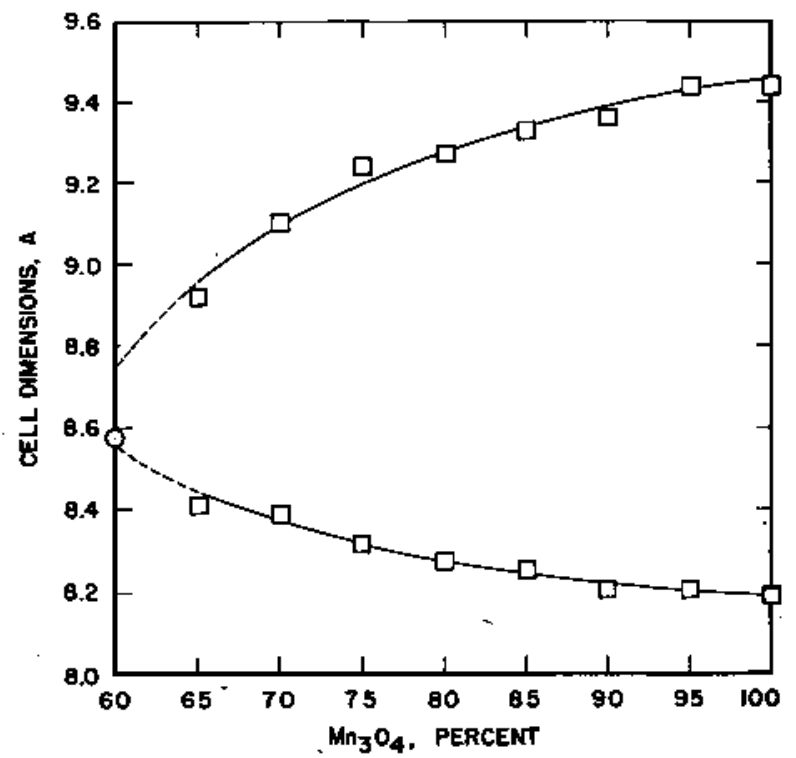

Figure 3. Unit-cell dimensions at room temperature of compositions in the system $\mathrm{Fe}_{3} \mathrm{O}_{4}-\mathrm{Mn}_{3} \mathrm{O}_{4}$.

$\square$, T'etragonal phase: $O$, euhie phase.

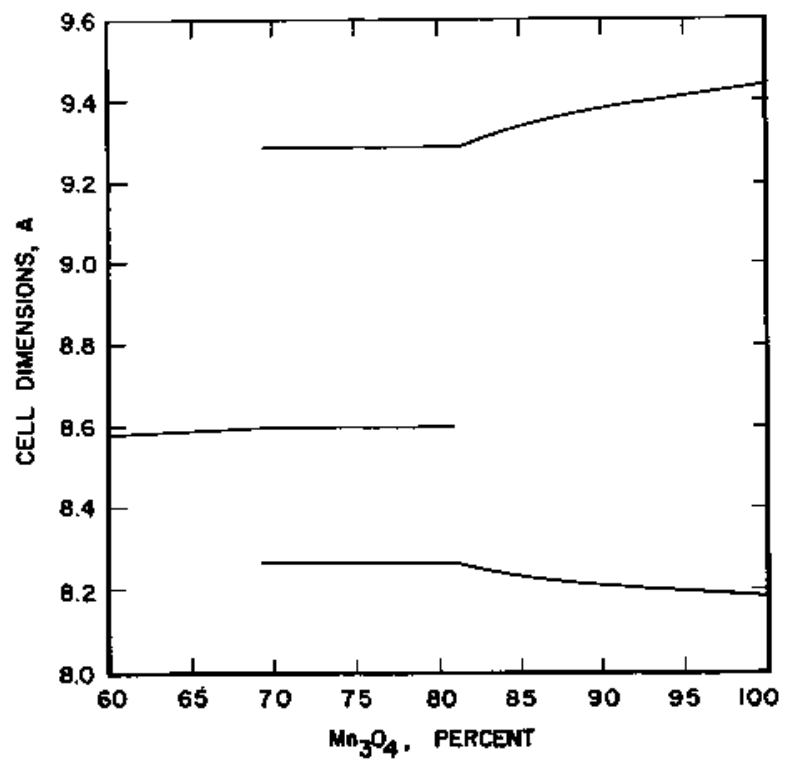

Figdre 4. Unit-cell dimensions of the system $\mathrm{Fe}_{3} \mathrm{O}_{4}-\mathrm{Mn}_{3} \mathrm{O}_{4}$ at $600^{\circ} \mathrm{C}$.

\section{Discussion}

Whercas the end compounds of the series $\mathrm{Fe}_{3} \mathrm{O}_{4}-\mathrm{Mn}_{3} \mathrm{O}_{4}$ are of the cubic and tetragonal structure, respectively, at room temperature, the unit cells of the two compounds have been shown to be very similar. As iron and manganese have similar atomic radii, it is not surprising to find that the two oxides are completely miscible at room temperature and form a series of substitutional solid solutions. If the unit-cell dimensions at room temperature are plotted for the series of compositions between $\mathrm{Fe}_{3} \mathrm{O}_{4}$ and $\mathrm{Mn}_{3} \mathrm{O}_{4}$ [4], it is found that the size of the cubic cell increases regularly until a composition of about 60 percent of $\mathrm{Mn}_{3} \mathrm{O}_{4}$ is reached, at which point the cubic lattice is no longer stable. When the composition exceeds 60 percent of $\mathrm{Mn}_{3} \mathrm{O}_{4}$, the cubic lattice becomes deformed and a tetragonal lattice results. The axial ratio increases continuously from unity at about 60 percent of $\mathrm{Mn}_{3} \mathrm{O}_{4}$ to 1.15 at 100 percent of $\mathrm{Mn}_{3} \mathrm{O}_{4}$. The volume of the unit cell increases almost lincarly with the substitution of manganese throughout the whole range of compositions. This behavior is typical of substitutional solid solutions.

Although $\mathrm{Fe}_{3} \mathrm{O}_{4}$ and $\mathrm{Mn}_{3} \mathrm{O}_{4}$ appear to be completcly miscible in tho solid state at room temperature, a two-phase region has been found at higher tempcratures. For example, at $600^{\circ} \mathrm{C}$ manganese may be substituted for iron to obtain a single cubic phase until a composition of about 69 percent of $\mathrm{Mn}_{3} \mathrm{O}_{4}$ (by weight) is reached. Likewise, iron may replace manganese in the tetragonal structure of $\mathrm{Mn}_{3} \mathrm{O}_{4}$, giving a single tetragonal phase. When a composition of 81 percent of $\mathrm{Mn}_{8} \mathrm{O}_{4}$ and 19 percent of $\mathrm{Fe}_{3} \mathrm{O}_{4}$ is reached, however, no more iron will go into the structure of $\mathrm{Mn}_{3} \mathrm{O}_{4}$. For this reason, there is a range of compositions at this particular temperature within which each sample is a mixture of two phases.

The vredenburgite occurring in nature usually shows two phases, cubic and tetragonal. Mason believed that this two-phase mineral, rather than the prepared samples, represented equilibrium conditions at room temperature, and that the compositions of the two phases making up the mineral therefore represented the limiting values of the solubility of $\mathrm{Mn}_{3} \mathrm{O}_{4}$ in $\mathrm{Fe}_{2} \mathrm{O}_{4}$ and of $\mathrm{Fe}_{3} \mathrm{O}_{4}$ in $\mathrm{Mn}_{3} \mathrm{O}_{4}$ at normal temperatures and pressures. In 
his survey of the minerals comprising the system $\mathrm{Fe}_{3} \mathrm{O}_{4}-\mathrm{Mn}_{3} \mathrm{O}_{4}$, he designated as vredenburgite those substances whose compositions lie within the area of immiscibility, that is, between 54 and 91 percent of $\mathrm{Mn}_{3} \mathrm{O}_{4}$. He arrived at these limits by examining samples of vredenburgite and comparing the lattice dimensions of each of the two phases present with those of a series of preparations that covered all compositions from $\mathrm{Fe}_{3} \mathrm{O}_{4}$ to $\mathrm{Mn}_{3} \mathrm{O}_{4}$ at intervals of 10 mole percent.

The present investigation shows that there is no region of immiscibility at room temperature and that Mason's criterion for establishing the limits of composition for vredenburgite is not based on equilibrium conditions at room temperature.

Mason also found specimens in the range from 54 to 91 percent of $\mathrm{Mn}_{3} \mathrm{O}_{4}$, which consisted of a single tetragonal phase. Believing that the singlephase type was a high-temperature form not in equilibrium at room temperature, he proposed calling it $\alpha$-vredenburgite and reserved the name $\beta$-vredenburgite for the two-phase material. In choosing these designations, Mason followed the convention that the high-temperature form should be indicated by the prefix $\alpha$. However, the present study indicates that the two-phase form ( $\beta$-vredenburgite) is the one that is stable at higher temperatures. To prevent confusion, it is suggested that Mason's designations be retained, the two-phase material being called $\beta$-vredenburgite.

Figure 5 is a photomicrograph of $\beta$-vredenburgite from India. The cubic phase appears as a black background, upon which the bright lines due to the tetragonal phase may be seen. As this material is unstable at room temperature, we must assume that, in cooling, the specimen remained in the two-phase region long enough for fairly large crystals of the tetragonal phase to form by exsolution. Subsequent cooling must have been rapid enough so that reaction between the two phases could not proceed and a degree of quenching took place.

Figure 6 is a photomicrograph of natural hausmannite from Sweden that shows polysynthetic twinning, as has been noted previously, [5] typical of material that has undergone a simple inversion [12]. In this case, the material must have had the cubic spinel structure before cooling through the inversion temperature.

Because of the difficulty in distinguishing iron

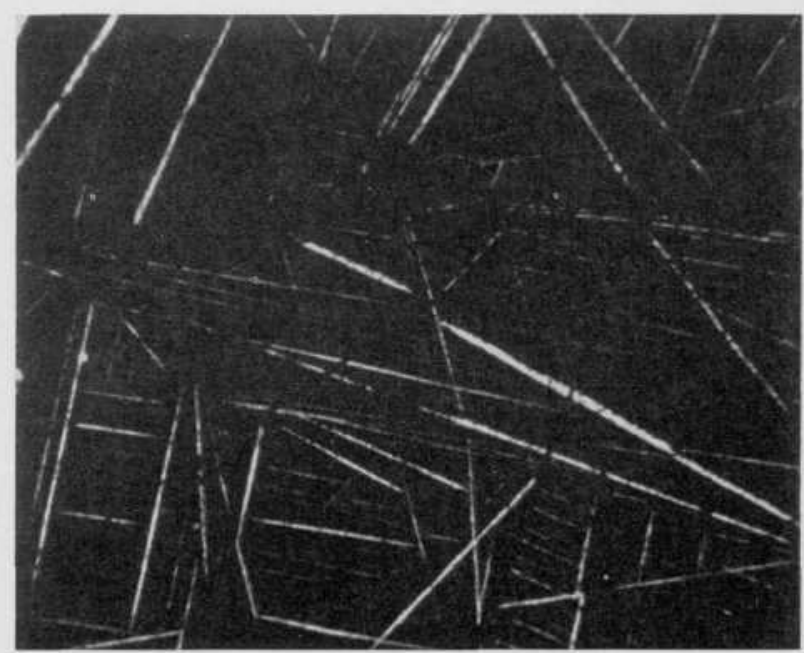

FigURE 5. Photomicrograph of $\beta$-vredenburgite from India by reflected polarized light.

The tetragonal phase appears as bright lincs and the cubic phase as the dark background. $\times 180$.

from manganese by their difference in scattering power, no information could be obtained about the distribution of cations among the positions available in the spinel structure. Barth and Posnjak [13] have shown that even the valence of a particular atom does not determine which metal position it will assume.

\section{Summary}

At room temperature, $\mathrm{Fe}_{3} \mathrm{O}_{4}$ and $\mathrm{Mn}_{3} \mathrm{O}_{4}$ appear to be completely miscible in the solid state. Manganese may be substituted for iron in the

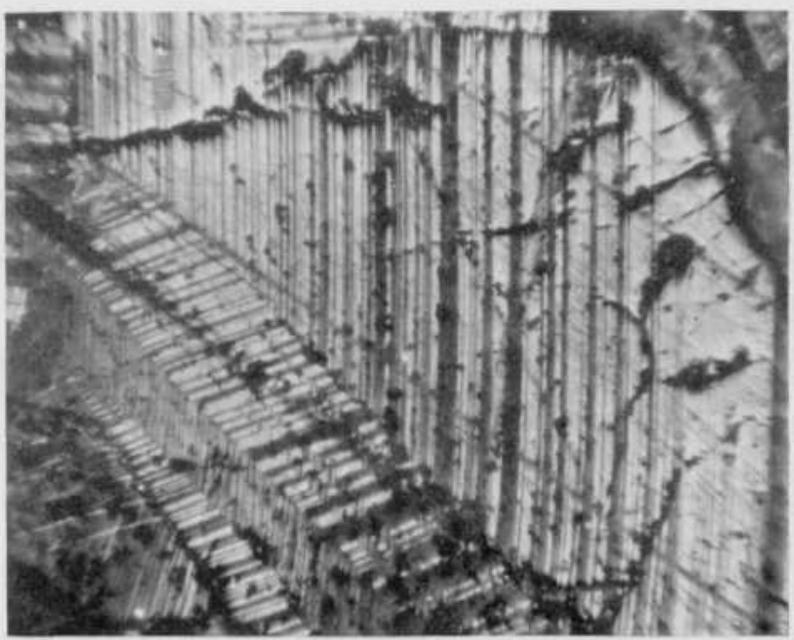

Figure 6. Pholomierograph by reflected polarized light showing polysynthetic twinning of hausmannite from Sweden. $\times 180$. 
cubic spinel-type structure of $\mathrm{Fe}_{3} \mathrm{O}_{4}$ until a composition of about 60 percent by weight of $\mathrm{Mn}_{3} \mathrm{O}_{4}$ is reached. Compositions containing more manganese takeon the tetragonal strueture of pure $\mathrm{Mn}_{3} \mathrm{O}_{4}$, and the axial ratio increases continuously from unity at 60 percent of $\mathrm{Mn}_{3} \mathrm{O}_{4}$ to 1.15 at 100 percent.

The volume of the unit cell increases regularly with the addition of nianganese.

In the temperature range from $380^{\circ}$ to $1,170^{\circ}$ $\mathrm{C}$, compositions above 60 percent of $\mathrm{Mn}_{3} \mathrm{O}_{4}$ are not completely miscible. When a composition with the tetragonal structure is heated, a temperature is reached at which a cubic phase of the spinel type starts to form. This cubic phase is in equilibrium with the tetragonal phase over a range of temperatures that depends on the composition. The percentage of tetragonal material decreases with further heating until a temperature is reached at which all the material has the cubic spinel-type structure. From this temperature up to the melting point, only the cubic phase is present.

The natural two-phase mineral $\beta$-vredenburgite is not at equilibrium at room temperature. The one-phase mineral $\alpha$-vredenburgite is the lowtemperature form.

\section{References}

[1] H. F. McMurdie and E. Golovato, Study of the modi- fications of manganese dioxide, J. Research NBS 41, 589 (1948) RP1941.

[2] G. Aminoff, The Crystal strueture of hausmannite, $\mathbf{Z}$. Krist. 64, 475 (1926).

[3] R. W. G. Wyckoff, The structure of erystals, 2d ed,, p. 297 (Reinhold Publishing Corp., 1931).

[4] B. Mason, Mineralogical aspects of the system FeO-Fe $\mathrm{O}_{3}-\mathrm{MnO}-\mathrm{Mn}_{2} \mathrm{O}_{3}$, Geol, Fören. Förh. 65, 97 (1943).

[5] J. Orcel and S. Pavlovitch, Les caractéres microscos piques des oxydes de manganese et des manganitenaturels, Bul. soc. franc. minéral. 54, 108 (1931).

[6] H. Sehneiderhohn and P. Ramdohr, Lehrbuch der erzmikroskopie, 2, 602, Berlin (1931).

[7] B. Mason, $\alpha$-Vredenburgite, Geol. Fören, Förh. 65, 263 (1943).

[8] H. Von Eckermann, Some remarks on the system $\mathrm{Fe}_{3} \mathrm{O}_{4}-\mathrm{Mn}_{3} \mathrm{O}_{4}$, Geol. Fōren. Förh. 65, 258 (1943).

[9] V. Montoro, Miscibilita fra gli ossidi salini di ferro e di manganese, Gass chim. ital. 68, 728 (1938).

[10] B. Mason, Mineralogieal aspects of the system, $\mathrm{Fe}_{3} \mathrm{O}_{4}-\mathrm{Mn}_{3} \mathrm{O}_{4}-\mathrm{ZnMn}_{2} \mathrm{O}_{4}-\mathrm{ZnFe}_{2} \mathrm{O}_{4}$, Am. Mineral. 32, 426 (1947).

[11] A. Van Valkenburg, Jr., and H. F. McMurdie, High temperature $\mathrm{X}$-ray diffraction apparatus, J. Research NBS 38, 415 (1947), RP1782.

[12] H. Le Chatelier, The constitution of hydraulic mortars p. 53 (McGraw-Hill Book Co., Inc., New York, N. Y., 1905).

[13] T. F. W. Barth and E. Posnjak, Spinel structures, Z. Krist. 82, 325 (1932).

WASHINGTON, March 29, 1950. 